\title{
MENGGUGAT KEBHINEKAAN: RESPON INTELEKTUAL MUDA PROGRAM PASCASARJANA UNIVERSITAS ISLAM NEGERI RADEN FATAH PALEMBANG TERHADAP KEPEMIMPINAN NON MUSLIM
}

\author{
Izzomiddin
}

\begin{abstract}
In the Islamic intellectual tradition, there are three issues that are always discussed regarding political leadership within the state. First, the question of less worthy leaders (imāmatul mafül). Secondly, the question of the immoral leader (imāmatul fāsiq). And third, the question of non-Muslim leaders (imämatul käfir). This dynamic becomes urgent to be studied, especially in the domain of non-Muslim leaders (imāmatul kāfir). The growing questions are: (1) What is the young intellectual response of UIN Raden Fatah Graduate for non-Muslim leadership?; (2) How does the strategic move to strengthen diversity by minimizing the non-Muslim leadership debate of young intellectual perspectives of Graduate UIN Raden Fatah Palembang ?. Both of them are effective, especially the contribution to build diversity that gives togetherness and peace in Indonesia. Being a subject of further study is mainly strengthening the concept of pluralist leadership.
\end{abstract}

Keyword: tradition, leadership, intellectual

\begin{abstract}
Abstrak
Dalam tradisi intelektual Islam, ada tiga persoalan yang selalu dibicarakan terkait kepemimpinan politik dalam negara. Pertama, soal pemimpin yang kurang layak (imāmatul mafụūl). Kedua, soal pemimpin yang suka maksiat (imāmatul fāsiq). Dan ketiga, soal pemimpin non-Muslim (imämatul käfir). Dinamika tersebut menjadi urgen untuk ditelaah terutama dalam ranah pemimpin non-Muslim (imāmatul käfir). Pertanyaan yang berkembang atas hal tersebut adalah (1) Bagaimana respon intelektual muda Pascasarjana UIN Raden Fatah atas kepemimpinan non muslim?; (2) Bagaimana langkah strategis mengokohkan kebhinekaan dengan meminimalisir perdebatan
\end{abstract}


kepemimpinan non muslim perspektif intelektual muda Pascasarjana UIN Raden Fatah Palembang ?. Kedua nya berdaya guna terutama kontribusi dalam membangun kebhinekaan yang memberikan kebersamaan dan kedamaian di Indonesia. Menjadi bahan kajian lanjutan terutama penguatan konsep kepemimpinan yang pluralis.

Kata Kunci: Tradisi, Kepemimpinan, Intelektual

\section{A. Pendahuluan}

Jurnal ini merupakan hasil penelitian yang dibiaya DIPA UIN Raden Fatah tahun 2017 berjudul Menggugat Kebhinekaan: Respon Intelektual Muda Program Pascasarjana Universitas Islam Negeri Raden Fatah Palembang Terhadap Kepemimpinan Non Muslim penting. Studi ini penting karena persoalan memilih kepemimpinan non muslim menjadi bacaan multi tafsir yang banyak dipengaruhi berbagai sebab yang pada beberapa tafsir mengalami kerancuan berpikir dalam memilah antara sumber hukum Islam tersebut dengan hasil ijtihad yang dapat dikritisi (qabil li al-niqash). Alih alih perdebatan akan selalu berkembang pada setiap kali ada peristiwa pemilihan kepala daerah atau presiden di Indonesia. Contoh yang paling kontemporer-fenomenal adanya calon incumbent yang non-Muslim, Basuki tjahja Purnama yang dikenal dengan Ahok yang kembali mencalonkan gubernur Jakarta tahun 2017.

Disamping hal tersebut, studi ini juga penting menilai mindset intelektual muda terutama di perguruan tinggi Islam seperti di universitas yang menjadi objek penelitian, penilaian ini akan memberikan simpulan ilmiah atas sikap dan argumentasi kepemimpinan non muslim di negera mayoritas muslim berkonstitusi Pancasila (Romli, 2013). Analisis jawaban atas penelitian ini walau tidak langsung berhubungan dengan tema sentral akan berimplikasi pengembangan pada kajian kebolehan umat Islam bekerja kepada kepemilikan atau pimpinan perusahaan milik nonmuslim. Pada sisi kegunaan, penelitian ini menjadi salah satu kajian penting pada beberapa mata kuliah pada program studi di Fakultas Sosial dan Ilmu Politik UIN Raden Fatah Palembang yang salah satu misinya untuk menghasilkan lulusan yang memiliki integritas keilmuan, kebangsaan, dan keislaman.

Dalam tradisi intelektual Islam, ada tiga persoalan yang selalu dibicarakan terkait kepemimpinan politik dalam negara. Pertama, soal pemimpin yang kurang layak (imāmatul mafụūl). Kedua, soal pemimpin yang suka maksiat (imāmatul fāsiq). Dan ketiga, soal pemimpin non-Muslim (imāmatul kāfir). Dalam tradisi ketiga, secara umum dealiktika kepemimpinan non muslim di Indonesia sudah mulai sejak adanya isu LB Moerdani akan dicalonkan menjadi wakil presiden mendampingi Soeharo pada 1988, isu menjadi makin memperdalam perdebatan manakala munculnya pernyataan Abddurahman Wahid (Gusdur) yang memunculkan bolehnya non muslim memimpin Indonesia (Mujar, 2006: ix).

Perkembangan atas persoalan kepemimpinan non muslim muncul lagi dengan konsep klasifikasi wilayah, yaitu pertama, memilih pemimpin non muslim di daerah mayoritas muslim; dan kedua, memilih pemimpin non muslim di daerah minoritas muslim. Perbincangan ada 
dalam klasifikasi pertama, yaitu memilih pemimpin non muslim di daerah mayoritas muslim atau di wilayah muslim. Sedangkan memilih pemimpin non muslim di daerah minoritas muslim ada pengecualian, sebagai suatu strategi untuk melindungi umat Islam dari bahaya yang akan menimpa mereka (QS. Ali Imron: 28).

Pro kontra dialog terus berkembang dengan berbagai argumentasi namun disisi lain kepemimpinan di beberapa daerah oleh non muslim juga berjalan, bahkan di berbagai negara yang dipimpin oleh non muslim tidak mengalami kekisruhan apalagi sampai menghancurkan demokrasi di masing masing negara. Pertanyaan yang selalu dipertanyakan adalah bagaimana sikap kaum muslimin dalam memilih calon pemimpin yang non muslim? Jika lanjutkan kemudian bagaimana cara menjaga semangat toleransi dalam memilih calon pemimpin yang berbeda agamanya dengan mayoritas muslim?

Ada dua asumsi yang muncul yang menjadi dasar penelitian ini, yaitu: Pertama, Adanya trauma sejarah mayoritas umat Islam yang mengalami jajahan dalam pemerintahan para kolonialis, khususnya Belanda selama 3,5 abad. Trauma tersebut terus dipelihara yang tetap melarang pemimpin non muslim; Kedua, Asumsi dialogis yang dijadikan standar polemik pelarangan kepemimpinan non-muslim berakar politisasi agama, yaitu politik manipulasi mengenai pemahaman dan pengetahuan keagamaan/kepercayaan dengan menggunakan cara propaganda, Indoktrinasi, kampanye, disebarluaskan, sosialisasi dalam wilayah publik dilaporkan atau diinterpretasikan agar terjadi migrasi pemahaman, permasalahan dan menjadikannya seolaholah merupakan pengetahuan keagamaan/kepercayaan, kemudian, dilakukan tekanan untuk memengaruhi konsensus keagamaan/kepercayaan dalam upaya memasukan kepentingan sesuatu kedalam sebuah agenda politik pemanipulasian masyarakat atau kebijakan publik (lihat, Wahid; Marijan; Murod Al-Brebesy, Mengurai Hubungan Agama dan Negara, 2000: 176; Cholil, 2008: 198; Denny J.A.; Fransiskus, Surdiasis, 2006: 45).

Dalam konsep ini, berbagai tulisan telah merespon negatif. Rumadi (http://hizbut-tahrir. or.id,) menjelaskan bahwa ketidaksetujuan agama hanya digunakan untuk kepentingan politik jangka pendek memenangkan pemilu. Dalam kajiannya menyebutkan.

Apalagi kemudian setelah menang pemilu, agama ditinggalkan seperti yang selama ini terjadi. Tradisi elit-elit politik cenderung mendadak Islami menjelang pemilu. Mulai dari pakai kopiah, sholat jum'at, sampai kunjungan ke pesantren dan majelis ta'lim. Setelah menang pemilu, wassalam. Rakyat membutuhkan pemimpin bukan sekedar sholih secara ritual. Tapi pemimpin sholih secara politik, pemimpin yang mau menerapkan syariah Islam, pemimpin yang mau mencampakkan ideologi dan sistem kapitalisme.

Politisasi agama melalui isu kepemimpinan non Muslim, diungkapkan Munawir Sjadzali (1990: 89)

...Satu hal lagi yang menarik, Ibnu Taimiyah mendambakan ditegakkannya keadilan sedemikian kuat, sehingga dia cenderung untuk beranggapan bahwa kepala negara yang adil meskipun kafir adalah lebih baik daripada kepala negara yang tidak adil meskipun Islam, dengan menyetujui ungkapan bahwa Allah mendukung negara yang adil meskipun kafir, dan bahwa Allah tidak mendukung negara yang tidak adil sekalipun Islam. 
Wawan Gunawan dalam tulisan "Fikih Kepemimpinan Non Muslim" (2015; 321; Arif Tripada, http://www.kompasiana.com) menjelaskan:

...bahwa di tempat lain Ibn Taimiyah menegaskan bahwa keadilan merupakan syarat terpenting bagi seorang pemimpinan. Sedemikian pentingnya tentang keadilan ini, Ibn Taimiyah dalam Majmu' al Fatawa bab XXVIII menyatakan:

$$
\text { إن الله يقيم الدولة العادلة وإن كانت كافرة ولا يقيم الظالمة و إن كانت مسلمة. ويقال: }
$$

Sesungguhnya Allah menyokong negara yang adil meskipun kafir (pemimpinnya) dan tidak mendukung negara yang despotic meskipun Muslim (pemimpinnya). Dunia itu dapat tegak dengan memadukan antara kekufuran dan keadilan dan dunia tidak dapat tegak dengan modal kezhaliman dan keislaman. "Kalimat Ibn Taimiyah tersebut mengisyaratkan bahwa kepala negara yang mampu mengejawantahkan keadilan meskipun non muslim lebih baik daripada kepala negara yang beragama Islam tetapi tidak mampu mengejawantahkan keadilan. ... "Memilih pemimpin non muslim di tengah masyarakat muslim hukumnya diperbolehkan. Itu dirujuk pada dua hal. Pertama, masalah kepemimpinan dalam hukum Islam merupakan persoalan yang bukan absolute (al mutaghayyirat). Kedua, larangan memilih pemimpin non muslim dikaitkan dengan sebab yang menyertainya, manakala mereka (non muslim) melakukan penistaan kepada umat Islam.

Mereka yang menentang "keharaman kepemimpinan non muslim" dinilai tidak memahami secara mendalam ayat ayat al-Qur'an maupun al-hadits baik dari sisi maksud dan tafsirnya, tidak melacak sebab-sebab turunnya ayat-ayat kepemimpinan dan cenderung mempermainkan makna harfiahnya dan menunjukkan kekeliruan yang fatal. Sementara mereka yang mengharamkan kepemimpinan non muslim menyebutkan mereka yang menjadikan orang kafir sebagai pemimpin bagi umat Islam berarti menentang Allah SWT dan Rasulullah SAW serta Ijma' Ulama.

Pandangan yang menyatakan bahwa memilih orang kafir sebagai pemimpin umat Islam berarti memberi peluang kepada orang kafir untuk "mengerjai" umat Islam dengan kekuasaan dan kewenangannya. Mereka berpegang pada (1) QS. Ali 'Imraan: 28; (2) QS. An-Nisaa': 144; (3) QS. Al-Maa-idah: 57; (4) QS. At-Taubah: 23.(5) QS. Al-Mujaadilah: 22. Badruddin AlHamawi As-Syafi'i (1998) menyatakan dengan jelas keharaman memilih pemimpin dan juga aparat dari kalangan kafir dzimmi. Dalam tulisannya disebutkan:
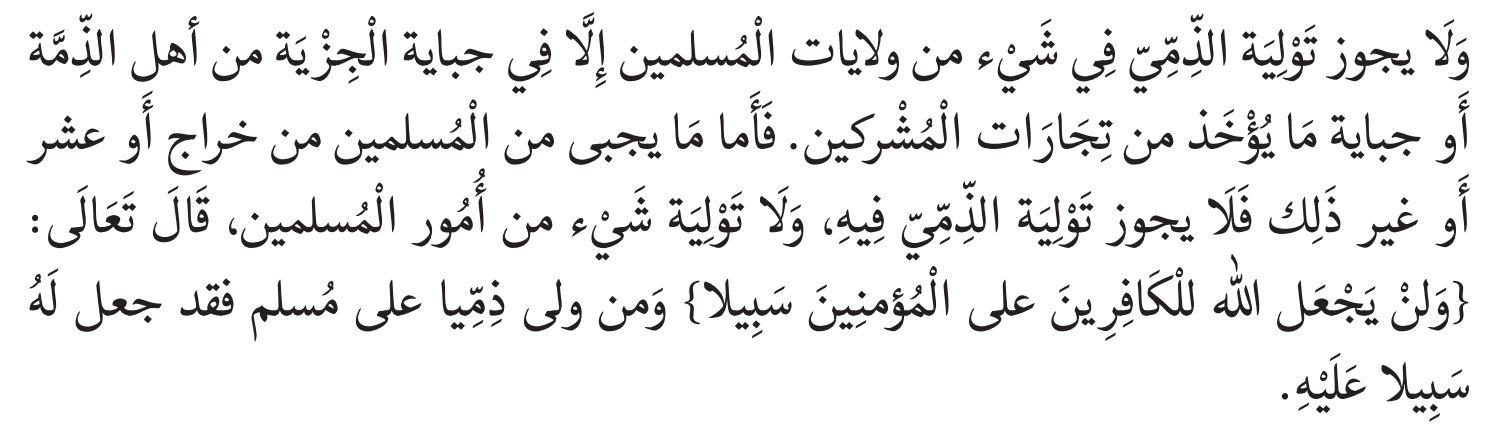
(Tidak boleh mengangkat dzimmi untuk jabatan apapun yang mengatur umat Islam kecuali untuk memungut upeti penduduk kalangan dzimmi atau untuk memungut pajak transaksi jual-beli penduduk dari kalangan musyrikin. Sedangkan untuk memungut upeti, pajak seper sepuluh, atau retribusi lainnya dari penduduk muslim, tidak boleh mengangkat kalangan dzimmi sebagai aparat pemungut retribusi ini. Dan juga tidak boleh mengangkat mereka untuk jabatan apapun yang menangani kepentingan umum umat Islam. Allah berfirman, "Allah takkan pernah menjadikan jalan bagi orang kafir untuk mengatasi orang-orang beriman." Siapa yang mengangkat dzimmi sebagai pejabat yang menangani hajat muslim, maka sungguh ia telah memberikan jalan bagi dzimmi untuk menguasai muslim).

Deliar Noer, dalam bukunya Islam dan Pemikiran Politik menulis sebagai tanggapan atas Islam dan Tata Negara: Ajaran, Sejarah dan Pemikiran oleh Munawir Syadzali MA yang menjelaskan adanya kesalahpahaman memahami Ibnu Taimiyah yang menganggap bahwa kepala negara yang adil meskipun kafir adalah lebih baik daripada kepala negara yang tidak adil meskipun Islam, dengan menhyetujui ungkapan bahwa Allah mendukung negara yang adil meskipun kafir, dan bahwa Allah tidak mendukung negara yang tidak adil sekalipun Islam. Justru pembicaraan Ibnu Taimiyah itu adalah dalam kontek negara Islam. Buktinya Ibnu Taimiyah mensyaratkan pemimpin itu harus bisa jadi imam minimal harus bisa shalat dan harus selalu mendekatkan diri kepada Allah Swt. Kejeasan pandangannya ditulis Hamawi:

... Memang Ibnu Taimiyah menekankan sekali agar seorang pemimpin itu adil, dan tentulah kepala negara termasuk di sini. Tetapi, pemimpin itu harus bisa menjadi imam shalat; sekurang-kurangnya ia harus bisa shalat. Ibnu Taimiyah memperkuat argumentasi dengan ayat-ayat Al Qur'an dan Hadits Nabi, juga dengan pendapat beberapa shahabat dan ulama (al-Siyasat al-Syar'iyah, 1961 bagian I bab I)..... Ibnu Taimiyah berbicara tentang negara bukan dalam arti genus (umum) melainkan dalam arti species (khusus), yaitu negara Islam. Tentu tidak mungkin diharap bahwa kepala negara yang kafir melakukan shalat umpamanya. Malah bagi Ibnu Taimiyah jihad terhadap mereka yang ingkar merupakan wajib (bagian II bab I). Di Bagian II bab 8 ini Ibnu Taimiyah mengatakan bahwa menegakkan kepemimpinan atau pemerintahan adalah wajib dengan maksud "mendekatkan diri kepada Allah" (al Siyasat al Syar'iyah, 1961, hal 166).

Sementara pada sisi lain dimunculkan pemberitaan secara massif di media tentang beberapa figur non-Muslim yang 'sowan' ke berbagai pondok pesantren dan ndalem kiai-kiai sepuh dengan tujuan membawa aspirasi para ulama dan umat Islam pada umumnya. Beberapa kalangan yang disowan'i ini pun menyambut dengan begitu meriah, bahkan seringkali terlihat kebablasan seperti foto-foto yang beredar di media tentang santriwan-santriwati yang mencium tangan laki-laki non-Muslim tersebut. Dari pertarungan antara penentang dan pendukung terhadap kepemimpinan non muslim menimbulkan berbagai persoalan yang membangun kecurigaan adanya upaya menggugat kebhinekaan yang dilakukan umat Islam. Karenanya penelitian ini layak untuk ditelaah secara empiris.

\section{B. Kajian Pustaka}


Studi yang berhubungan dengan kepemimpinan non muslim telah dibahas dalam berbagai perspektif. Kajian kepemimpinan dan hubungannya dengan toleransi Islam dibahas oleh Jhon Oneill (2009) yang mengangkat tema Islam and Demise of Clasical civilization (Perang-Perang Suci Islam dan Matinya Peradaban Klasik), hasil penelitian menyimpulkan bahwa Meskipun Islam atau kekuatan Islam disebarkan melalui pedang, adalah benar bahwa pada pengikut dari agama-agama lainnya pun, khususnya "Agama- agama dari Para Ahli Kitab" diijinkan untuk tetap mempraktekkan iman mereka. Iman-iman lainnya, seperti Budhisme dan Hinduisme yang mana kelompok-kelompok ini kemudian dikenal sebagai dhimmi, atau berstatus "dilindungi". Orang-orang Yahudi dan Kristen harus membayar pajak yang disebut jizya, sementara pajak itu sendiri tidak diberlakukan pada orang-orang Muslim. Kecuali pajak ini, orang-orang Yahudi dan Kristen memiliki kesetaraan yang hampir sama di hadapan hukum dengan orangorang Muslim, toleransi hanya pada aspek kebutuhan tersebut, namun kepemimpinan mereka minoritas harus tunduk dengan aturan yang berlaku di mayoritas muslim dan ini maknanya bahwa umat Islam menutup diri terhadap kepemimpinan non muslim.

Wahyu Naldi dalam (2015) penelitiannya yang mengkomparasi pemikiran Quraish Syihab dengan Sayyid Qutb Terhadap Penafsiran ayat ayat kepemimpinan non Islam memberikan kesimpulan bahwa Sayyid Qutb secara tekstual dengan tegas melarang pemimpin non muslim, sementara Quraish Shihab memahami ayat secara holistik dan kontekstual, sehingga membolehkan kepemimpinan non muslim di negara mayoritas muslim dengan syarat. Beberapa penelitian yang juga telah mengkaji kepemimpinan non muslim seperti dilakukan Abu Thalib Khalik (2014), Rahmad Syarifuddin (2016).

Ahmad Agha Mahir dalam penelitiannya yang kemudian ditulis dalam buku yang diterjemahkan berjudul Yahudi; Catatan Hitam Sejarah (2011: 118) menyimpulkan bahwa berkaitan dengan pengangkatan seorang pemimpin negara yang mengatur pemerintahan, seorang tersebut haruslah beragama Islam. Di dalam al-Qur'an dengan tegas Allah Swt melarang kaum mukmin untuk menjadikan orang kafir sebagai wali, pemimpin ataupun orang kepercayaan, yang dikarenakan dikhawatirkan mereka akan berkhianat dan membuat kerusakan dengan berbuat dosa di muka bumi. Larangan tersebut tercantum dalam surah QS. ali-Imrān ayat 28. Menurutnya pelarangan itu bukan tanpa sebab, karena sejarah telah membuktikan tabiat orang non-Muslim dan betapa kerasnya kaum non-Muslim telah secara terang-terangan memperlihatkan permusuhannya terhadap kaum Muslimin.

Penelitian yang mengkaji pemimpin non muslim telah dilakukan oleh Ilham yang pada tahun 2015 meneliti masyarakat Lenteng Agung Jakarta dalam memahami pemimpin non muslim. Dalam kesimpulannya, masyarakat lenteng agung yang rata rata santri mengharamkan pemimpin non muslim. Sementara Surya Adinata berjudul Analisis terhadap Penafsiran FPI Mengenai Ayat Pemimpin Non-Muslim yang memahami ayah secara tekstual menyimpulkan dengan tegas pemimpin non muslim di Indonesia (Jurnal Ushuluddin, Vol.2, Nomor. 2. JanuariJuni 2015: 146). Persamaan dengan penelitian sebelumnya adalah dalam penelaahan teoritisasi pemimpin Non Muslim, sementara perbedaan dalam penelaahan pada kedalaman kajian, terutama alasan yang menjadi dasar bagi pendukung dan penentang pemimpin non muslim. 


\section{Teoritisasi Kajian}

Konsep penting dalam penelitian ini adalah menggugat kebhinekaan yang dinilai dari isu pemimpin non muslim. Istilah menggugat yang dikutip dari Kamus Bahasa Indonesia adalah mengguncangkan, mengadukan, menuntut (janji); membangkit-bangkitkan perkara yg sudahsudah, mencela dengan keras; menyanggah (https://www.kamusbesar.com/menggugat). Sementara dari aspek kebhinekaan merupakan wujud dari kontrak sosial masyarakatnya, bernaung dalam satu lingkup identitas yang disimbolkan dengan bendera. Kebhinekaan merupakan realitas bangsa yang tidak dapat dipungkiri keberadaannya. Untuk mendorong terciptanya perdamaian dalam kehidupan Bangsa dan Negara (Latif, 2011: 324). Kebhinekaan pun harus dimaknai masyarakat melalui pemahaman multikulturalisme dengan berlandaskan kekuatan spiritualitas. Nilai Pancasila dan UUD 1945 mengarahkan semua strata masyarakat untuk mengimplemtasikan:

1. Menghormati Hak Asasi Manusia sesuai dengan UUD 1945;

2. Menjunjung tinggi harkat dan martabat semua anak bangsa Indonesia;

3. Mengakui persamaan hak-hak semua kelompok, agama, ras dan etnis dalam segala tatanan kehidupan sosial, politik, ekonomi, budaya dan pemerintahan;

4. Menghargai perbedaan yang ada dalam masyarakat sebagai kemajemukan yang semakin memperkaya khasanah kehidupan berbangsa dan bernegara;

5. Mendorong terwujudnya kedamaian dalam perbedaan;

6. Memajukan kerja sama dengan para pemangku kepentingan untuk mewujudkan kehidupan yang humanis di segala bidang;

7. Tidak melakukan kekerasan dan penindasan dalam bentuk apapun, kepada siapapun, dan atas nama apapun (Karim, 2000: 172).

Simbol yang muncul dari Bendera, Bhineka Tunggal Ika akan memberikan nilai kesadaran bahwa kita bangsa satu, bukan Aceh, Batak, Palembang, Jawa, Sunda, Papua, tidak ada kata "aku" dan "kamu" tapi dalam bahasa "kita". Ideologi dasar ini sebenarnya menjadi kunci bahwa siapapun wajib untuk sama sama membangun dan menguatkan komponen negara secara bersama sama dan dalam bidang keahlian masing masing. Keanekaragaman budaya, suku, bahasa, agama yang ada di Indonesia menjadi sebuah peluang sekaligus tantangan bagi bangsa untuk mempertahankan kebhinekaan. Satu sisi menjadi penguat asset kesejahteraan namun disisi lain globalisasi dengan berbagai ideologi serta kekuatan teknologi menjadi ancaman kesemerawutan nilai kebersatuan. Unsur Identitas dengan rumusan pembagian sebagaimana dalam tabel berikut:

Tabel 1

Pembagian Dan Unsur Nasionalisme-Kebhinekaan

\begin{tabular}{|l|l|l|}
\hline No & Pembagian & Unsur \\
\hline 1 & Identitas fundamental (Pancasila, Dasar Negara, & 1. Pancasila \\
& Ideologi Negara) & 2. Dasar Negara \\
& & 3. Ideologi negara \\
\hline
\end{tabular}




\begin{tabular}{|l|l|l|}
\hline 2 & Identitas instrumental & 1. UUD 1945 \\
& & 2. Bahasa Indonesia, \\
& & 3. Lambang Negara \\
& & 4. Bendera Negara, \\
& & 5. Lagu Kebangsaan "Indonesia Raya \\
\hline 3 & Identitas alamiah & 1. Ragam Suku \\
& & 2. Ragam Bahasa \\
& & 3. Ragam Budaya \\
& & 4. Agama \\
& & 5. Ragam Kepercayaan \\
\hline
\end{tabular}

Sumber: Olah Data 2017

Teori yang digunakan dalam menilai respon intelektual muda terhadap pemimpin non muslim dilihat melalui 3 varian hubungan pemikiran politik Islam juga menampilkan dua spektrum pandangan tentang hubungan antara yang berkuasa dan yang dikuasai. Perbedaan pandangan ulama politik tidak lepas dari perbedaan akar tradisi pemikiran sebagaimana terlihat dalam trikotomi yang pernah dirumuskan oleh Bahtiar Effendy (1998: 28), M. Din Syamsuddin (1993: 8-9) dan juga diikuti oleh William Liddle (1998: 283-311) dalam konsep Negara.

Dari rumusan ketiganya, disimpulkan adanya tiga varian hubungan yang masing-masing mempunyai dikotomis. Yaitu: pertama, skripturalistik berhadapan rasionalistik. Skripturalis menampilkan pemahaman yang bersifat tekstual dan literal, sedangkan paham rasionalis menolaknya menampilkan penafsiran rasional dan kontekstual, lalu melahirkan pandangan berbeda mengenai negara; kedua, varian idealistik berbeda paham paham dengan penganut realistik. Varian idealis cenderung melakukan idealisasi terhadap sistem pemeritahan dengan menawarkan nilai-nilai Islam ideal, sedangkan varian realisme cenderung menerima format negara yang ada; dan ketiga, varian formalistik berbeda dengan varian substansialistik. Varian formalistik lebih mengedepankan bentuk dari pada isi, sedangkan substantivistik lebih mengedapankan isi dibandingkan bentuk (Maliki, 2000: 13).

Ketiga varian ini kemudian membentuk polarisasi sistem kenegaraan yang dari rumusan ketiganya, disimpulkan adanya tiga varian hubungan yang masing-masing mempunyai dikotomis. Yaitu: pertama, skripturalistik berhadapan rasionalistik. Skripturalis menampilkan pemahaman yang bersifat tekstual dan literal, sedangkan paham rasionalis menolaknya menampilkan penafsiran rasional dan kontekstual, lalu melahirkan pandangan berbeda mengenai negara; kedua, varian idealistik berbeda paham paham dengan penganut realistik. Varian idealis cenderung melakukan idealisasi terhadap sistem pemeritahan dengan menawarkan nilai-nilai Islam ideal, sedangkan varian realisme cenderung menerima format negara yang ada; dan ketiga, varian formalistik berbeda dengan varian substansialistik. Varian formalistik lebih mengedepankan bentuk dari pada isi, sedangkan substantivistik lebih mengedapankan isi dibandingkan bentuk (Maliki 2000: 10; Suyitno, Heri Junaidi, 2009).

Ketiga varian ini akan menjadi dasar bagaimana respon pemimpin non muslim dalam konsep negara Indonesia, Oleh karenanya perangkat konsep dari masing-masing varian pemikiran akan digunakan sebagai pedoman dalam pengumpulan data termasuk menjawab semua pertanyaan 
yang ada dalam penelitian ini.

\section{Metodologi}

Teori dalam penelitian ini berangkat dari teori eksploratif dan kohesi. Dengan demikian pendekatan ilmunya adalah ilmu politik, dan fiqh siyasah yang relevan dimana kedua disiplin itu diharapkan dapat memecahkan persoalan dalam penelitian ini. Pendekatan datanya adalah kualitatif. Dari itu metode yang adalah wawancara sehingga menemukan substansi dari dari jawaban rumusan masalah penelitian ini. Akhirnya penulisan menjurus kepada essai berupa deskripsi sehingga menemukan model yang berlaku di lingkungan penelitian ini.

Di satu sisi, pengumpulan data dilakukan dengan kajian pustaka untuk mendapatkan pemahaman riil tentang Kepemimpinan serta ideologi pendukung keduanya; di sisi lain, pengumpulan data dilakukan terhadap pemahaman intelektual muda Pascasarjana UIN Raden Fatah Palembang terhadap pokok bahasan penelitian ini. Untuk itu sumber data primer adalah respon para responden. Pemilihan terhadap responden kalangan inteletual muda yang sedang kuliah di pascasarjana program magester dan doktoral dengan beberapa alasan peneliti (12 Maret 2017), Hasil FGD) sebagai berikut:

1. Tingkat Pemahaman keberagamaan mereka diindikasikan sudah "dewasa"

2. Tingkat usia yang diindikasikan mapan dalam memikirkan, menjawab dan membangun solusi terutama terhadap kajian penelitian ini

3. Keluasan pandangan terhadap perkembangan wawasan kebangsaan, kenegaraan dan dinamika politik di Indonesia indikasikan telah cukup mumpuni dalam menjawab persoalan.

Jumlah responden dalam penelitian ini adalah sebagai berikut:

Tabel 2

Responden Penelitian Terpilih

\begin{tabular}{|c|c|c|c|c|}
\hline \multirow[t]{2}{*}{ No } & \multirow[t]{2}{*}{ Program } & \multicolumn{3}{|c|}{ Jumah/Semester (Mahasiswa) } \\
\hline & & $1-2$ & 3-4 & 5> \\
\hline 1 & Strata 2 (Magester) & 1 & 2 & 2 \\
\hline 2 & Strata 3 (Doktoral) & 2 & 4 & 4 \\
\hline \multicolumn{2}{|r|}{ Jumlah } & 3 & 6 & 6 \\
\hline & Total Responder & \multicolumn{3}{|c|}{15 orang } \\
\hline
\end{tabular}

Sumber: FGD Tim pelaksana, 2017

Tehnik pengumpulan data melalui wawancara untuk mendapatkan respon dan alasan masing-masing baik yang mendukung dan yang menentang. Karena datanya kualitatif, pengelolahannya dilakukan dengan tabulasi hingga kategorisasi-kategorisasi data sesuai pedoman wawancara, hasil observasi serta bukti-bukti pendukungnya lainnya. Setelah itu dilakukan analisa serta interprestasi tentang data tersebut. Untuk hal tersebut pertanyaan-pertanyaan umum yang berfungsi sebagai pedoman dalam penyusunan model peliputan datanya terbagi dalam dua bagian, yaitu:

1. Respon atas kepemimpinan non muslim 
a. Apa yang dipahami dengan kepemimpinan?

b. Apa pendangan ketika mencuat perdebatan "Pemimpin Non Muslim" di Indonesia?

c. Setujukah jika gerakan tersebut dilakukan dengan menggunakan massa mengatasnamakan "Aksi Damai"?

d. Bagaimana menilai perdebatan tersebut dihubungkan dengan suksesi kepemimpinan?

e. Bagaimana Menilai perdebatan tersebut dihubungkan dengan isu Sara?

f. Apakah perdebatan tersebut sebagai upaya adanya gerakan gugatan terhadap kebhinekaan di Indonesia menuju perpecahan bangsa?

2. Langkah strategis mengokohkan kebhinekaan

a. Apa yang harus dilakukan dalam meminimalisir perdebatan pemimpin non muslim?

b. Apa langkah strategis yang bisa menjadi wadah mediasi perdebatan yang mengokohkan kebhinekaan di Indonesia?

c. Jika langah itu diterapkan seberapa besar kemungkinan ide strategis dapat diterima semua masyarakat di Indonesia?

\section{E. Kepemimpinan dan Kebhinekaan dalam Perspektif}

1. Pemimpin dan Kepemimpinan

Istilah pemimpin berasal dari kata dasar "pimpin" yang dalam Kamus Besar Bahasa Indonesia (KBBI) diartikan sebagai "bimbing atau tuntun". Kata kerja dari kata dasar ini, yaitu "memimpin" yang berarti "membimbing atau menuntun". Dari kata dasar ini pula lahirlah istilah "pemimpin" yang berarti "orang yang memimpin" (Kata pemimpin mempunyai padanan kata dalam Bahasa Inggris "leader". Sementara itu kata "pemimpin” mempunyai kaitan yang sangat erat dengan kata "kepemimpinan" (KBBI, 2005: 874).

Kepemimpinan adalah kemampuan yang dimiliki dari seorang pemimpin. Dengan kata lain, kepemimpinan juga dapat diartikan sebagai kemampuan untuk memimbing dan menuntun seseorang. Jika tadi kata pemimpin mempunyai padanan kata dalam Bahasa Inggris (leader), maka kepemimpinan juga mempunyai padanan kata dalam Bahasa Inggris yaitu leadership. Kata ini berasal dari kata dasar "lead" yang dalam diartikan sebagai "show the way, especially by going in front". Sementara itu kata "leadership" diartikannya sebagai "qualities of a leader" (Manser, 1995: 236).

Pemimpin di suatu organisasi, memiliki posisi yang dominan dalam menentukan maju mundurnya suatu perusahaan/organisasi. Kinerja yang dihasilkan oleh suatu perusahaan/ organiasi gambaran kepemilikan hasil yang diberikan oleh pemimpin yang mengelola perusahaan/organisasi tersebut.dan stakeholders terbiasa menjadikan kinerja sebagai salah satu ukuran dalam mendukung pengambilan keputusan. Seorang pemimpin yang baik adalah yang mampu mengelola seluruh sumber daya yang dimiliki dan mampu memberikan keuntungan serta kepuasan kepada stakeholders. Seorang pemimpin harus memahami tentang kepemimpinan (Safaria, 2012: 27).

Kata "kepemimpinan" dari asal "pimpin" dipahami dengan kemampuan yang 
dimiliki seseorang untuk memengaruhi orang-orang untuk bekerja mencapai tujuan dan sasaran. Sementra pemimpin adalah suatu peran atau ketua dalam sistem di suatu organisasi atau kelompok. Winardi menyebutkan bahwa kepemimpinan adalah suatu kemampuan yang melekat pada diri seorang (pimpinan) dalam dua ranah yaitu (1) pemimpin formal (formal leader) dan atau (2) pemimpin informal (informal leader) [Winardi, 2000: 32].

Suradinata (2008) menjelaskan bahwa pemimpin adalah orang yang memimpin kelompok dua orang atau lebih, baik organisasi maupun keluarga, sementara kepemimpinan adalah kemampuan seorang pemimpin untuk mengendalikan, memimpin, mempengaruhi pikiran, perasaan atau tingkah laku orang lain untuk mencapai tujuan yang telah ditentukan sebelumnya. Dalam pemahaman yang lain Kepemimpinan berasal dari kata pimpin artinya tuntun, bimbing yang mendapatkan imbuhan ke-an yang artinya menjadi perihal memimpin, cara memimpin. Dapat diartikan sebagai hubungan yang erat antara seorang dan sekelompok manusia karena adanya kepentingan bersama, hal itu ditandai oleh tingkah laku yang tertuju dan terbimbing dari manusia yang satu itu yang disebut pemimpin atau yang memimpin (Ensiklopedia Umum: 549). Kepemimpinan juga dipahami dengan kemampuan seseorang dalam mempengaruhi suatu kelompok untuk mencapai tujuan (Robbin, 2012: 163). Menurut Ngalim Purwanto Kepemimpinan adalah sekumpulan dari serangkaian kemampuan dan sifatsifat kepribadian, termasuk di dalamnya kewibawaan untuk dijadikan sebagai sarana dalam rangka meyakinkan yang dipimpinnya agar mereka mau dan dapat melaksanakan tugas-tugas yang dibebankan kepadanya dengan rela, penuh semangat, ada kegembiraan batin, serta merasa tidak terpaksa (Purwanto, 2000: 4).

Dari berbagai pemahaman dapat diktahui bahwa kepemimpinan adalah kemampuan pemimpin untuk mempengaruhi perilaku orang lain menuju keinginan-keinginannya dalam suatu keadaan tertentu mengarahkan, mempengaruhi, dan mengawasi orang lain untuk mengerjakan tugas sesuai dengan perintah yang direncanakan.

Dalam dunia Melayu, pemimpin didefinisikan sebagai orang yang diberi kelebihan untuk mengurus kepentingan orang banyak. Seorang raja haruslah sosok manusia yang dapat dijangkau oleh rakyat biasa. Penguasa harus berada di tengah-tengah rakyatnya, mengerti kondisi warganya, dan tahu apa yang diinginkan oleh mereka. Raja bukanlah dewa yang tak tersentuh oleh manusia. Dalam A Handbook of Leadership di akumulasi pemimpin dan kepemimpinan (1) a Focus Of Group Process (Kepemimpinan sebagai titik pusat proses kelompok); (2) Leadership As Personality And Its Effects (Kepemimpinan sebagai kepribadian seseorang yang memiliki sejumlah perangai (traits) dan watak (character) yang memadai dari suatu kepribadian); (3) the art of inducing comliance (seni untuk menciptakan kesesuaian paham, kesepakatan); (4) the exercise of its influence (sebagai pelaksanaan pengaruh); (5) As act or behavior (sebagai tindakan atau prilaku); (6) from of persuasion (bentuk persuasi); (7) a power relation (suatu hubungan kekuasaan/kekuatan); (8) an Instrumental Of Goal Achievement (sarana pencapaian tujuan) [Stogdill, 1974).

Salah sebuah konsep kepemimpinan yang merupakan warisan kebudayaan bangsa adalah Hastha Brata, atau delapan ajaran keutamaan, seperti yang ditunjukkan oleh sifat-sifat alam 
(Mulyana, 2005; Kartika, 2007). Ki Hadjar Dewantara merumuskan kepemimpinan sosial dengan tiga ungkapan Ing ngarso sung tulodho (didepan memberi contoh); Ing madyo mangun karso (di tengah memberi semangat) Tut wuri handayani (di belakang memberikan daya kekuatan) [Hanin, 2002]. Konsep kepemimpinan tersebut dikembangkan masa kepemimpinan Soeharto dalam bentuk: Pertama, Surya yaitu matahari yang memancarkan sinar sebagai sumber kehidupan; Kedua, Candra yaitu bulan memancarkan sinar kegelapan malam. Cahaya bulan yang lembut mampu menumbuhkan semangat dan harapan-harapan yang indahal. Seorang pemimpin hendaknya mampu memberikan dorongan atau motivasi untuk membangkitkan semangat rakyatnya,dalam suasana suka dan duka.

Ketiga, kartika yaitu bintang yang memancarkan sinar indah kemilau, mempunyai tempat yang tepat dilangit hingga dapat menjadi pedoman arahal. Seorang pemimpin hendaknya menjadi teladan, untuk berbuat kebaikan. Tidak ragu menjalankan keputusan yang disepakati, serta tidak mudah terpengaruh oleh pihak yang akan menyesatkan. Keempat, angkasa yaitu langit. Langit itu luas tak terbatas, hingga mampu menampung apa saja yang datng padanya. Seorang pemimpin hendaknya mempunyai keluasan batin dan kemampuan mengendalikan diri yang kuat, hinga dengan sabar mampu menampung pendapat rakyatnya yang bermacam-macam.

Kelima, Maruta yaitu angin. Angin selalu ada dimana-mana, tanpa membedakan tempat serta selalu mengisi semua ruang ruang yang kosong. Seorang pemimpin hendaknya selalu dekat dengan rakyat, tanpa membedakan derajat dan martabatnya, bisa mengetahui keadaan dan keinginan rakyatnya. Mampu memahami dan menyerap aspirasi rakyat. Keenam, samudera yaitu laut/air. Laut, betapapun luasnya, senantiasa mempunyai permukaan yang rata dan bersifat sejuk menyegarkan. Seorang pemimpin hendaknya menempatkan semua orang pada derajat dan martabat yang sama, sehingga dapat berlaku adil, bijaksana,dan penuh kasih sayang terhadap rakyatnya.

Ketujuh, dahana yaitu api. Api mempunyai kemampuan untuk membakar habis dan menghancurleburkan segala sesuatu yang bersentuhan dengannya. Seorang pemimpin hendaknya berwibawa dan berani menegakkan kebenaran dan keadilan secara tegas dan tuntas tanpa pandang bulu. Kedelapan, bumi yaitu bumi/tanahal. Bumi mempunyai sifat kuat dan murah hati. Selalu memberi hasil kepada siapapun yang mengolah dan memeliharanya dengan tekun.seorang pemimpin hendaknya berwatak sentosa, teguh dan murah hati, senang beramal dan senantiasa berusaha untuk tidak mengecewakan kepercayaan rakyatnya (Junaidi, 2008).

Dengan demikian dasarnya bangsa Indonesia telah memiliki berbagai macam corak gaya kepemimpinan, salah satunya adalah Kepemimpinan dalam tradisi melayu oleh nilai-nilai religius, baik oleh agama Islam maupun agama-agama yang lain (Arthur, 2009:37; Effendi, 2002)..Hal tersebut memberikan implikasi bahwa dalam tradisi melayu seorang pemimpin bisa jadi diukur dengan bagaimana kualitas seseorang dalam melaksanakan ajaran agamanya atau bahkan gaya kepemimpinannya didasarkan pada cara pandang suatu agama. Hal tersebut menjadi menarik karena pemimpin dalam tradisi melayu mencoba untuk menerjemahkan berbagai dogma agama kedalam kehidupan nyata, baik dalam skala mikro maupu makro dalam masyarakat (Braginsky, 2000: 55).

Dalam budaya Melayu menjelaskan bahwa pemimpin merupakan sosok manusia yang 
dapat dijangkau oleh rakyat biasa, mampu berada di tengah-tengah rakyatnya, mengerti kondisi warganya, dan tahu apa yang diinginkan oleh mereka. Dibangun kebijakan untuk tidak saling merusak posisi masing-masing melalui musyawarahal. Beberapa syair yangmenjelaskan kedudukan pemimpin dan kepemimpinan:

Sebagai pemimpin banyak tahunya

Tahu duduk pada tempatnya

Tahu tegak pada layaknya

Tahu kata yang berpangkal

Tahu kata yang berpokok

Sebagai pemimpin banyak bijaknya

Bijak menyukat sama papat

Bijak mengukur sama panjang

Bijak menimbang sama berat

Bijak memberi kata putus

Manajemen kepemimpinan dalam konstruk nilai-nilai politik Islam yang dibangun terletak pada pola manajemen kerakyatan yaitu sistem pengelolaan sumber-sumber daya yang ada baik dari aspek manusia, kekuatan ekonomi, politik, teknologi, militer, dengan mengikuti normanorma yang hidup di dalam masyarakat banyak. Pada fase perjalanan panjang selanjutnya, Indonesia sebagai negara yang menganut paham demokrasi Pancasila mempunyai ciri khas yang selalu didengungkan pada aspek materielnya ialah kekeluargaan dan kegotong royongan bernafaskan Ketuhanan yang Maha Esa. Dijabarkan oleh S. Pamudji (1985: 12):

Yang dimaksud dengan kekeluargaan ialah kesadaran untuk lebih mendahulukan penunaian kewajiban sosial daripada penuntutan hak pribadi, lebih mengutamakan memadukan pendapat dengan jalan musyawarah daripada menekankan pendapat sendiri.....pengambilan keputusan didasarkan pada atas dasar musyawarah dan mufakat, sehingga tidak akan terjadi dominasi mayoritas dan tirani minoritas, karena keduanya tidak selaras dengan semangat kekeluargaan dan kegotong royongan"

Dalam kajian Islam terdapat hubungan sangat erat antara kepemimpinan dan konsep negara dalam pandangan Islam.. Adagium adalah "tiada agama tanpa kelompok/masyarakat, tiada masyarakat tanpa kepemimpinan dan tiada kepemimpinan tanpa sang pemimpin "(La dina Illa bi jamáatin wa la tama'ata illa bi imamatin wa la imamata illa bi imamin). Di sini tampak jelas, arti seorang pemimpin bagi Islam, ia adalah pejabat yang bertanggung jawab tentang penegakan perintah-perintah Islam dan pencegah larangan-larangan Nya (Amar Máruf Nahi Munkar).

Pemimpin negara adalah faktor penting dalam kehidupan bernegara. Jika pemimpin negara itu jujur, baik, cerdas dan amanah, niscaya rakyatnya akan makmur. Sebaliknya jika pemimpinnya tidak jujur, korup, serta menzalimi rakyatnya, niscaya rakyatnya akan sengsara. Oleh karena itulah Islam memberikan pedoman dalam memilih pemimpin yang baik. Dalam 
Al Qur'an, Allah SWT memerintahkan ummat Islam untuk memilih pemimpin yang baik dan beriman (QS. 60. Al-Mumtahanah : 1: Q.S At Taubah: 23; “An Nisaa:144; Q.S. Al-Maidah: 57)

\section{F. Kepemimpinan Non Muslim: Sketsa Awal}

Isu kepemimpinan menjadi pusat perhatian media. Media online maupun media massa( koran dan majalah ) tidak luput memberitakan isu kepemimpinan, bahkan tidak sedikit yg menjadi headline. Misalnya, Kepemimpinan seorang Basuki tjahja Purnama atau yg biasa disebut Ahok selalu ramai menjadi rebutan headline di media. Mayoritas penduduk Indonesia beragama islam. Sehingga cenderung menginginkan pemimpin muslim, ketika Ahok muncul dengan pelbagai kontroversinya.

Beberapa pandangan seperti argumentasi bahwa jika arab Saudi itu jelas dalam konstitusinya menyebut mereka sebagai negara islam. Sedangkan Indonesia kontitusinya menyebutkan sebagai negara ber Pancasila, sehingga non muslim layak menjadi pemimpin di Indonesia (Pernyataan Djayus , dosen Hukum Tata Negara Universitas Jember. http://www.kompasiana.com/wazilmuhammed) . "Dalam surah al maidah 57 dijelaskan bahwa seorang mukmin dituntut untuk memilih seorang aulia ( pemimpin ), dari kalangan yg menjaga sebuah agama agar tidak menjadi bahan ejekan dan permainan. Sehingga jelas bahwa carilah pemimpin yg cenderung menjaga kehormatan agama apapun (Pernyataan M Noor Harisuddin. http://www.kompasiana.com)

Dalam halaqah bahtsul masail kiai muda pimpinan pusat gerakan pemuda ansor "kepemimpinan non muslim di indonesia" sebagai respon atas kegelisahan Gerakan Pemuda Ansor ketika melihat Islam dipolitisasi sedemikian berlebihan dan menghakimi pihak yang berbeda preferensi politiknya sebagai bukan Islam.Kecenderungan intoleransi sesama umat Islam semakin kasat mata dan tergambar dengan adanya spanduk di sejumlah masjid yang tidak menerima pengurusan jenazah Muslim bagi pemilih dan pendukung calon pemimpin nonMuslim. Oleh karena itu, Pimpinan Pusat Gerakan Pemuda Ansor menyatakan beberapa hal berikut:

1. Mengenai prinsip berbangsa dan bernegara, kami memandang bahwa dengan diterimanya NKRI, UUD 1945 dan Pancasila sebagai sebuah kesepakatan para pendiri bangsa, yang salah satunya adalah tokoh NU KHal. Wahid Hasyim, maka sebagai warga NU, kami menerima sistem bernegara dan berbangsa dalam bingkai NKRI. Dan karena itu, produk turunan dari konsititusi itu sah dan mengikat bagi warga NU dan tentunya warga Indonesia pada umumnya.

2. Tentang terpilihnya non-Muslim di dalam kontestasi politik, berdasarkan konstitusi adalah sah jika seseorang non-Muslim terpilih sebagai kepala daerahal. Dengan demikian keterpilihannya untuk mengemban amanah kenegaraan adalah juga sah dan mengikat, baik secara konstitusi maupun secara agama.

3. Sebagai warga negara yang beragama (dalam ranah pribadi) boleh memilih atau tidak memilih non-Muslim sebagai pemimpin formal pemerintahan. Karena kami melihat, hal ini sebagai persoalan yang masih dalam tataran khilafiyah (debatable), sehingga masing- masing 
pandangan yang menyatakan wajib memilih Muslim maupun boleh memilih non- Muslim sebagai kepala pemerintahan memiliki landasan dalam hukum Islam.

4. Karena itu, Halaqah Bahtsul Masail Kiai Muda GP Ansor menghimbau kepada umat Islam di Indonesia untuk meredakan ketegangan pada setiap kontestasi politik, karena hal tersebut dapat berpotensi memecah belah umat Islam dan NKRI. Dengan demikian, siapapun yang setuju atau tidak setuju, memiliki landasan hukum agama (fiqh) yang dapat dibenarkan. Namun dalam hal khilafiyah (debatable) hendaknya masing-masing tetap memegang teguh etika amar makruf dan tata krama perbedaan pendapat.

5. Menyikapi fenomena yang terjadi akhir-akhir ini dimana muncul pandangan sebagian kelompok untuk tidak mensholatkan jenazah lawan politik, GP Ansor berpendapat bahwa ini merupakan cerminan sikap yang tidak Islami juga tidak Indonesianis. Bagi GP Ansor, setiap jenazah Muslim tetap wajib disholatkan. Untuk itu jika tindakan seperti ini terus berlanjut, GP Ansor menyediakan diri untuk mensholatkan jenazah tersebut, termasuk mentahlilkan selama 40 hari.

Abdul Choir dalam tulisannya Menggugat Mazhab Kekuasaan dalam Fikih Kebhinekaan Versi Islam Nusantara menjelaskan dalam konstruksi nusantara mencatat bahwa Kata Nusantara tercatat pertama kali dalam literatur berbahasa Jawa Pertengahan (abad ke-12 hingga ke-16) untuk menggambarkan konsep kenegaraan yang dianut Majapahit. Nusantara berasal dari dua kata bahasa Sanskerta, yaitu Nusa yang berarti "pulau” dan Antara yang berarti "luar”. Jadi, pada awalnya kata Nusantara itu menunjuk pada "pulau lain" di luar Jawa dan merupakan daerah taklukan Majapahit. Ide penyatuan pulau-pulau di luar Jawa di bawah kekuasaan Majapahit inilah yang mendorong Majapahit melakukan ekspansi kekuasaan. Dapat dikatakan di sini, bahwa kata Nusantara lahir dalam konteks ekspansi kekuasaan di bawah kekuasaan absolut sang Raja. Barulah pada masa kekinian, Nusantara diartikan sebagai keterhubungan antar pulau, bukan sebaliknya. Sedangkan dalam Islam, kekuasaan bukan satu hal yang absolut. Kekuasaan diatur dan di bawah ketentuan syariat Islam. Syariat Islam juga tidak mengenal batas-batas yuridiksi kedaulatan negara dalam konteks modern sekarang. Jelasnya, Islam tidak mengenal teritorial. Islam itu satu dan merujuk pada yang satu (sama) yaitu Al-Qur'an dan As-Sunahal.

Lebih lanjut Abdul Khoir (http://www.voa-islam.com ) juga mencatat bahwa Islam Nusantara sebagaimana sedang digalakkan oleh pemerintah menunjuk kepada satu target besar, yakni menghadirkan pemerintahan yang lebih prima dibandingkan dengan sistem ajaran keagamaan Islam. Ide Islam Nusantara yang sedang diframekan dapat melahirkan satu Mazhab Kekuasaan dalam rangka melanggengkan rezim yang berkuasa. Jika Patih Gadjah Mada menyatakan dalam Sumpah Palapanya akan mengalahkan "pulau-pulau lain”, maka konsep Islam Nusantara akan menegasikan ajaran Islam yang tidak sejalan dengan pemikiran kaum Liberalis. Kaum Liberalis inilah yang akan menjadikan Islam Nusantara melalui Fikih Kebhinekaan sebagai Mazhab Kekuasaan. Ia kemudian menyatakan. Ajaran Islam tentang ketatanegaraan tidak lagi dilihat sebagai satu kebutuhan. Mazhab Kekuasaan itulah yang menjadi pilar bagi penguasa di Nusantara. Hal ini menjadi sama persis dengan tujuan ekspansi Patih Gadjah Mada. Gagasan Islam Nusantara, sejatinya adalah didasarkan kepada kepentingan politis kaum Liberalis 
yang memang terkenal "arogan dalam pemikiran”, menembus batas-batas toleransi intelektual. Pernyataan Jokowi "Islam kita adalah Islam Nusantara, Islam yang penuh sopan santun, Islam yang penuh tata krama, itulah Islam Nusantara, Islam yang penuh toleransi," menunjukkan ketidakmengertiannya tentang Islam. Pernyataan itu seolah-olah ingin mengatakan bahwa Islam di luar Nusantara, tidak mengedepankan sopan santun, tata karma, dan tidak ada toleransi. Toleransi yang dimaksudkan dalam konsep Islam Nusantara tidak lain mengacu kepada pemikiran HAM versi Barat yang memang mengusung kebebasan (liberty) secara absolut. Banyak pihak yang memang diuntungkan dengan konsep Islam Nusantara ini. Di bawah Islam Nusantara, semua pemikiran dan aliran sesat memiliki hak yang sama, tanpa ada pelarangan. Menjadi jelas, bahwa apa yang diperjuangkan dalam gagasan Islam Nusantara sebenarnya adalah untuk menjadikan sistem ketatanegaraan Indonesia ke arah kekuasaan belaka. Penguasa akan sangat dikuatkan dengan konsep Islam Nusantara melalui Fikih Kebhinekaan itu. Ciri khas Mazhab Kekuasaan adalah menjadikan hukum positif (Undang-undang) sebagai landasan kekuasaan. Di luar undang-undang bukanlah hukum... Tidak ada kata sepakat untuk menjadikan Indonesia sebagai Islam Nusantara. Islam lebih mulia dibandingkan dengan Nusantara. Nusantara adalah salah satu wilayah berlakunya hukum Islam. Sepantasnya, Nusantara yang harus menyesuaikan diri dengan nilai-nilai Islam, bukan sebaliknya. "Islam Yes", "Nusantara Oke”, tetapi "Islam Nusantara No".

\section{G. Intelektual Muda Pascasarjana UIN Raden Fatah}

Terbitnya Peraturan Presiden Nomor 129 tahun 2014 tentang Perubahan Institut Agama Islam Negeri Raden Fatah Palembang menjadi Universitas Islam Negeri Raden Fatah Palembang tidak hanya mengubah nama IAIN Raden Fatah Palembang menjadi Universitas Islam Negeri (UIN) Raden Fatah Palembang, tetapi juga membawa momentum perubahan yang sangat bermakna serta sarat dengan peluang dan tantangan. Pengembangan IAIN Raden Fatah Palembang yang beralih status menjadi UIN Raden memiliki berstandar kepada tiga core values, yaitu "internasionalisasi", "kebangsaan", dan "keislaman” yang terbangun dalam visi UIN Raden Fatah dengan langkah dasar yang diarahkan untuk menjadi lembaga pendidikan tinggi yang konsisten dalam menyelenggarakan pendidikan dan pengajaran ilmu-ilmu keislaman yang sejalan dengan tujuan pendidikan nasional. Termasuk program pascasarjana IAIN Raden Fatah menjadi Program Pascasarjana UIN Raden Fatah Palembang.

Perubahan tersebut membangun peran aktif intelektual muda pascasarjana dalam programprogram nasional bidang pendidikan dan pembinaan moral untuk menciptakan masyarakat madani (civil society) yang demokratis, egaliter, toleran dan saling menghormati perbedaan dalam kehidupan berbangsa dan bernegara (RIP UIN Raden Fatah Palembang 2015-2035, 2016: 3-4

Dalam mengembangkan suasana akademik, pascasarjana UIN Raden Fatah membuat dalan melaksanakan pengajian UKKAZ. Pengajian UKKAZ merupakan aktifitas kajian eksekutif yang diikuti oleh para mahasiswa pascasarjana, dosen dan undangan dari aktifitas intelektual muslim di Sumatera Selatan dengan para nara sumber ahli pada bidang nya. Disamping itu pascasarjana memiliki CRD (Center Research Depelovment) yaitu Pusat Pengembangan Penelitian UIN 
Raden Fatah Palembang merupakan unit akademik di bidang penelitian yang mengorganisir pengembangan penelitian di bidang studi Islam, sosial dan ekonomi, ilmu pengetahuan dan teknologi, psikologi dan pendidikan. Tujuan penelitian ini adalah untuk memenuhi visi, misi dan tujuan dari UIN Raden Fatah untuk menjadi International University.

Diantara kajian intelektual muda dalam berbagai kasus yang memperlihatkan problem sosial paling besar dalam kehidupan berbangsa dan bernegara di Indonesia yaitu (1) bagaimana teologi suatu agama mendifinisikan diri di tengah agama-agama lain; dan (2) bagaimana kelompok minoritas satu adat beradaptasi dengan kelompok mayoritas adat lainnya. Kedua hal ini berkembang dan di set-up dalam bentuk standar ganda yang diekstremkan dengan kalimat "bahwa hanya agama kitalah yang paling benar, yang lain salah atau telah menyimpang" (other religions are false paths that mislead their followers); dan "hanya adat dan daerah kitalah yang paling mulia sedangkan yang lain dalam kelompok strata kedua" (Lyden, 1995: 67).

Praktek standar ganda (double standars) tersebut, dimodifikasi dalam satu sisi standar untuk kelompok mereka bersifat ideal dan normatif, dan sisi lain bersifat realistis dan historis. Hal itu kemudian mencuat kepermukaan manakala tirani mayoritas atau hegemoni minoritas dalam satu daerah terbentuk baik secara spontan maupun diprovokasi. Maka kemudian terjadilah penghancuran etnis dan agama. Tragedi Ambon, Sampit dan Palangkaraya, Kalimantan Tengah, Sangir, Jakarta, bahkan di kepulauan Riau merupakan contoh-contoh daerah yang terkontaminasi kekerasan (violence) lingkaran adat dan agama. Maka disintegrasi bangsa terus berkembang di tengah kegalauan bangsa yang dipesona non gratakan akibat krisis ekonomi dan politik berkepanjangan.

Masalah-masalah yang menggayuti hubungan antar-agama, etnis di Indonesia hingga sekarang tidak pernah kunjung selesai secara tuntas, karena rezim pemerintah terdahulu sengaja memelihara "api dalam sekam" sebagai salah satu cara untuk mempertahankan status quo. Setting ini tidak lepas dari perasaan tidak cukup percaya diri dengan kekuasaannya sehingga selalu memainkan "kartu" dibawah dengan membiarkan sekat-sekat primordial tetap menajam (Jackson and Lucian W. Pye (ed.), 1976: 21). Djohan Effendi seperti dikutip dari Budhy Munawar Rahman, 2001: .xx) menyatakan "Rezim sengaja menanam bibit-bibit potensi konflik horizontal. Dengan diciptakannya peta hubungan sosial yang demikian itu, maka hubungan antar-umat beragama dan etnis memang menjadi rawan...."

Politik "Mendekamnya kerukunan" yang dipaksa-paksakan pada masa lalu juga merupakan faktor penentu menimbulkan konflik di kemudian hari, terutama setelah kran reformasi terbuka. Di tambah lagi belum adanya kesepakatan istilah "reformasi" di semua kalangan menambah tumbuh kembangkan kristal konflik tersebut. Setidaknya benih-benih keretakan di setiap daerah dengan simbol Jakarta sebagai ibukota negara muncul dalam beragam bentuk. Banyak pengamat dimintakan saran pendapat tentang unsur-

\section{H. Intelektual Muda Muslim Uin Raden Fatah Dan Kepemimpinan Non Muslim}

Dalam pengumpulan data penelitian ini dilakukan dengan wawancara secara bertahap 
dengan responden bervariasi mahasiswa program S2 dan S3. Masa wawancara dilakukan baik melalui share pemikiran di kelas maupun tanya jawab langsung, via telpon. Pelaksanaan wawancara dilakukan secara bertahap antara bulan Juni, Juli sampai minggu pertama bulan Agustus 2017 dengan responden 15 orang intelektual muda program Strata 2 dan strata 3. Hasil wawancara diolah baik dengan transkrip maupun deskriptif. Hasil penelaahan didapatkan atas kepemimpinan non muslim yangditelusuri melalui dasar pemahaman responden. Menurut para responden kepemimpinan adalah adalah seni dalam memimpin, kepemimpinan berbicara pada wilayah dimana sebuah usaha untuk mempengaruhi orang lain agar mencapai sesuatu tujuan dengan menjalan kan fungsi manajemen. Pemahaman juga disebutkan bahwa kepemimpinan adalah wakil Allah dimuka bumi (khalifatullah fi al-ardhi). Pemahaman responden disandarkan kepada hadits Rasulullah Saw. "Setiap kita pemimpin dan setiap yg kita pimpin akan dipinta pertanggung jawabannya. Dengan demikian pemimpin dan kepemimpinan adalah amanah dari Allah Swt, yang harus dipertanggungjawabkan di dunia dan akherat.

Responden lain memberikan pemahaman bahwa kepemimpinan adalah suatu cara yang keluar dari jiwa seorang pemimpin yang akan memberikan dampak terhadap lingkungan yang dipimpinnya, baik dampak positif ataupun negatif. semua dampak yang terjadi akan memberikan jawaban bagaimana kekokohan sikap seseorang dalam menjalankan pengabdiannya. Kemudian juga memaknai pemimpin adalah orang yang memiliki pola pikir, semangat dan berpikir moderat dalam mengatur bawahan. Dalam pandangan responden lain memberikan pemahaman bahwa kepemimpinan adalah seorang yang mampu berkomunikasi dan berkepribadian tegas dalam memutuskan sesuatu yang berhubungan dengan masyarakat atau bawahan (Deskripsi wawancara tanggal 16 Juli 2017)

Dari responden juga memberikan pernyataan bahwa kepemimpinan adalah merupakan pola seseorang dalam mengatur suatu komunitas melebihi dari lingkungannya tersebut. Kelebihan yang dimaksud adalah dari aspek komunikasi, kepintaran dan juga mungkin dari aspek fisik. Dalam berbagai konsep kepemimpinan banyak metoda yang dipahami dalam perspektif Islam pemimpin adalah orang yang memiliki kemampuan untuk mengatur, memperbaiki, mengajarkan dan mempengaruhi orang yang dipimpin sementara yang dipimpin mengikuti apa yang diperintahkan. Dalam konsepnya pemimpin memiliki visi masa depan mampu mengkomunikasikan visi tersebut melalui misi dan tujuan yang dipahami oleh yang dipimpin.

Responden juga menjelaskan bahwa kepemimpinan adalah kepemimpinan adalah suatu tahapan dimana seseorang pemimpin mampu menjadi suatu panutan ataupun acuan terhadap pengikut atupun rakyatnya. Sehingga apa yang menjadi tanggung jawab pemimpin tersebut dapat terlaksana dengan baik. Berdasarkan data pemahaman responden dapat dinilai, bahwa kepemimpinan merupakan seni berkomunikasi wakil Allah dimuka bumi (khalifatullah $f i$ alardhi) melalui pola pikir, semangat dan berpikir moderat dan visioner dalam mempengaruhi orang perorang dan masyarakat lain yang memberikan dampak terhadap lingkungan yang dipimpinnya.

Sejalan dengan pemahaman mereka tentang pemimpin dan kepemimpinan yang kemudian 
difokuskan pada perdebatan "Pemimpin Non Muslim" di Indonesia. Responden menilai dari sudut sistem demokrasi di Indonesia, sehingga menurut mereka menjadi hal yang sah-sah saja jika non muslim menjadi pemimpin. Ketika terjadi perdebatan maka titik dasar harus berpijak pada Negara Kesatuan Republik Indonesia (NKRI) yang dibangun oleh kebhinekaan yang tunggal ika, yang harus dimaknai sebagai media toleransi yang berlaku sama antar semua pihak (Olah dan analisis data wawancara, 2017). Beberapa responden lain menilai bahwa seorang muslim, tentunya ini merupakan berkenaan dengan Aqidah, yg jelas al-Quran menyatakan dalam ayatnya surat al-Maidah, Ayat 51, yg melarang seorang mukmin, untuk mengangkat seorang non muslim untuk menjadi wali atau pemimpin (Olah dan analisis data wawancara, 2017).

Responden lain memiliki kesamaan bahwa jika terjadi kepemimpinan dari non muslim menjadi sangat disayangkan. Menurut mereka, Umat Islam mayoritas dan memiliki orang orang yang mampu memimpin, mengapa kemudian harus berpikir ingin dipipimin oleh orang non muslim. Maka pergolakan masyarakat yang menerima merupakan wujud mereka kepada cinta tanah air, dan ketentraman bangsa Indonesia yang mayoritas muslim. Mereka meyakini bahwa mayoritas umat Islam di Indonesia memilih Imam yang mampu menjaga amanah, yang mengerti batasan-batasan dan nilai nilai keislaman, serta ketegasan bahwa Indonesia adalah Negara muslim mayoritas dan sudah selayak nya yang menjadi pemimpin adalah dari kaumnya. Hampir sejalan responden menyatakan:

Menurut pendapat saya, ketika adanya seorang pemimpin non muslim di Indonesia tentu menjadi suatu permaslahan yang cukup mengkhawatirkan. Seperti yang kita ketahui Indonesia memang bukanlah Negara islam namun perlu di ingatkan bahwasannya mayoritas penduduk di Indonesia beragama islam. Jadi, apabila hal tersebut terjadi akan membuat suatu keresahan terhadap masyarakat dan ini tentunya berdampak pada masyarakat di Indonesia. Maka apabila diadakan perdebatan mengenai pemimpin non muslim di Indonesia saya sangat mendukung / menyetujui kegitan tersebut.

Berdasarkan nilai telaah wawancara maka ada dua pandangan intelektual muslim pascasarjana UIN Raden Fatah ketika mencuat perdebatan "Pemimpin Non Muslim" di Indonesia. Kelompok yang menilai bahwa perdebatan tersebut tidak seharusnya ada sebab berbagai masalah masih menggayuti, mereka berpandangan jika berstandar pada demokratisasi Indonesia dan konsep besar Negara Republik Indonesia (NKRI) serta kebhinekaan. Sementara kelompok yang lain menilai bahwa perdebatan yang melelahkan seharusnya tidak perlu terjadi jika mayoritas umat Islam menyadari bahwa kepemimpinan mereka adalah seiman dan seagama. Dari kedua pandangan tersebut intelektual muslim UIN Raden Fatah meyadari pentingnya kesadaran semua komonen akan eksistensi diri jika ingin menjadi pemimpin. Walaupun tidak ada aturan yang menjelaskan, maka aturan kesadaran menjadi penting sebagai batasan untuk memimpin.

Dalam pernyataan lanjutan dengan pertanyaan atas gerakan menggunakan massa mengatasnamakan "Aksi Damai" dalam merespon kepemimpinan non muslim semua setuju. Karena konsepnya sudah dijamin Undang-Undang. Mereka memberikan argumentasi melalui 
aturan Dasar hukum demonstrasi adalah pasal 28 UUD 1945 dan UU No.9 Tahun 1998 dan tidak mengarah pada pasal penghasutan yang mengarah pidana.

Responden juga memberikan pandangan atas persetujuannya pada kata "aksi damai" yang berangkat dari panggilan hati untuk turun kejalan dan menundukkan diri dalam keramaian. Responden memberikan kesedihan jika mengingat sebab terjadinya aksi ini. namun disisi lain jiwa nasionalisme juga tetap dijaga, tidak ada aksi pemukulan ataupun perilaku menyimpang lainnya. aksi ini di nilai damai dari awal di lakukan hingga aksi ini bubar teratur.. Lebih lanjut salah seorang responden menyatakan:

Setuju, karena masyarakat dapat langsung berpartisipasi dalam menentukan layak atau tidak pemimpinnya, tanpa adanya tindakan kekerasan dari pihak manapun. Hal tersebut sesuai dengan aturan demon sekaligus aspirasi demokrasi semakin mendewasa dalam kegiatan kebersamaan di lapangan

Dari berbagai pernyataan yang dimunculkan pada saat wawancara dipahami bahwa aksi damai bagi mereka menutut keadilan dan ketegasan pemerintah untuk menghukum penistaan agama yang dilakukan oleh basuki tjahaja purnama/ahok/zhong wan xie. Dalam aksi tidak dibolehkan untuk membawa alat alat yang memicu menimbulkan anarkis menyerang berbagai fasilitas umum dan atau kata kata tidak bermoral. Responden kemudian juga menjelaskan

Menurut saya, adanya hal ini akan membuat suatu pertimbangan masyarakat dalam meningkatkan pengetahuan umum pemimpinnya. Maka seseorang yang berjiwa pemimpin dapat amanah dalam menjalankan tugasnya. Dan juga dengan adanya hal ini dapat membantu meningkatkan kesadaran masyarakat bahwasannya apa yang menjadi kepentingan terhadap umum dapat diwujudkan.

Seiring dengan penelaahan teologis terhadap kepemimpinan non Muslim, resonden juga diminta pandangan atas penilaian perdebatan Pemimpin Non Muslim tersebut yang dihubungkan dengan suksesi kepemimpinan. Beberapa responden merespon ulang dengan pertanyaan siapa sebenarnya yang mengaitkan ini dengan suksesi kepemimpinan, pihak yang pro dengan pemimpin non muslim kah?, atau sebaliknya yang kontra?. Bagi mereka kedua-dua nya menggunakan isu yang sama tapi berharap timbal balik yang berbeda, yang kesemua itu merupakan bagian dari strategi dan taktik masing-masing. Lebih lanjut salah seorang responden menjawab

Jika melihat suksesi kepemimpinan pemimpin non muslim saat ini memberikan dampak yang tidak baik terhadap keadaan negara, terlihat dalam perdebatan yang terjadi pemimpin non muslim menyisakan pergoyangan bhineka. karena sistem politik jika di kaitkan dengan masalah agama tentunya akan berbenturan. antara hak dan kewajiban. kewajiban umat muslim untuk memilih pemimpin muslim dan hak semua rakyat Indonesia menjadi seorang pemimpin. seperti dalam isi Pancasila dalam sila ke-lima, keadilan sosial bagi seluruh rakya Indonesia.

Dalam persepsi lain resonden menilai bahwa hal tersebut menjadi kewajaran, sebab ngara Indonesia adalah negara Demokrasi yg bebas untuk memilih pemimpin. Pernyataan diarahkan kedalam isu SARA, responden menilai bisa saja perdebatan tersebut dalam upaya 
mengkristalisasikan yang didesain melalui isu SARA. Hal tersebut sebagai salah satu bentuk perang asimetris yang dimainkan oleh pihak ketiga. Lebih luas responden menyatakan bahwa pola tersebut menjadi momen menyebarkan isu terhadap kedua belah pihak, salah seorang responden mengungkapkan:

.... keduanya dalam posisi yang sama dalam mencari jalan tengah, jika tidak disadari isu mengenai suku, agama, ras dan antar golongan akan menjadi penyebab perpecahan bangsa. jika dalam perdebatan masalah ini adalah akan terjadi diskriminasi terhadap suatu agama yang diyakini maka akan timbul kembali masalah penistaan agama. yang akan membawa permasalahan menjadi ujung pergolakan.

Sementara responden memberikan pernyataan ketidaksetujuan dan terlalu mengada ada jika suksesi kepemimpinan dan perdebatan sekitar pemimpin non muslim. Bagi mereka memilih pemimpin adalah hak preograti seseorang, yg tidak boleh diketahui oleh orang lain siapa yg kita pilih, yaitu menggunakan LUBER (Langsung, Umum, Bebas, dan Rahasia). Pertanyaan lebih difokuskan dengan asumsi perdebatan "pemimpin non muslim" tersebut sebagai upaya adanya gerakan gugatan terhadap kebhinekaan di Indonesia menuju perpecahan bangsa mereka memberikan pandangan dalam 3 pandangan yaitu:

Pertama, mereka memberikan penilaian adanya permainan pihak ketiga yang ingin Indonesia dengan agama-agama, dengan suku-suku dan adat, budaya di dalamnya terpecah belah, di adu domba didesain dari perang nonmiliter yang ampuh; Kedua, Tidak, karena pada prinsipnya kebhinekaan tidak akan terpecah hanya karena memilih pemimpin, kecuali adak yg memaksakan kehendak sehingga wajib memenangkan salah satu jagoannya, itu baru bisa berakibat perpecahan bangsa; Ketiga, menilai perdebatan dan aksi memunculkan dampak yang tidak baik terhadap persatuan Indonesia. karenanya hak dan kewajiban yang tidak proporsional apalagi sampai memaksakan kehendak berdampak bagi keutuhan bangsa dan ini artinya menghancurkan kebhinekaan. Sementara dari sisi lain responden memberikan pernyataan:

Tentu, karena walaupun dalam ketentuannya ini tidak bisa dipastikan secara khusus, namun apabila sesuatu dapat meresahkan masyarakat maka hal tersebut perlu ditindak lanjuti. Upaya untuk menyatukan suatu bangsa dapat dilakukan dengan hal lain tanpa memecah belah suatu persatuan. Dan juga perlu memperhatiakan kepentingan masyarakat umum.

Menganalisis berbagai pandangan responden dapat dinilai dari konsep dasar bahwa dalam kepemimpinan memiliki 2 kewenangan yaitu al-tafwid yaitu otritas pemimpin untuk menentukan kebijakan pemerintahannya (Q.S. An-Nisa: 141). Dalam menentukan kebijakan memerlukan berbagai langkah strategis. Langkah tersebut memerlukan kebersatuan pikir, keagamaan dan pandangan yang pro mayoritas agama; dan kedua, al tanfizh yaitu kebijakan birokrasi top down yang mampu melakukan berbagai kebijakan sesuai dengan kebijakan pusat. Dalam perspektif kepemimpinan non muslim klasifikasi kewenangan sangat diperlukan (alFarra', 1994; al-Bakr, 1988; Musa, t.t; Quthub, 1971)

Pertanyaan sekitar pencoblosan calon pimpinan (Bupati/Walikota/Gubernur) beragama non muslim dijawab dalam dua katagori yaitu haram dan bolehal. Bagi masyarakat muslim yang merasa bahwa memilih calon non muslim adalah haram, maka itu sudah ada argumen yang 
melandasinya, dan demikian pula bagi yang merasa bahwa memilih calon non muslim adalah boleh juga ada argumennya. Kesimpulan dalam acara Bahtsul Masail Kyai Muda Ansor bertema Kepemimpinan Non Muslimm, di Aula Iqbal Assegap, PP Ansorm Jakarta, pada 12 Maret 2017 memilih pendapat ke-1 atau ke-2 sama-sama benarnya, dan sama-sama muslimnya, serta tidak ada yang terhukumi sebagai kafir yang jenazahnya haram disholati. Semua masih tetap muslim dan semua tetap wajib dishalati.

\section{Langkah Mengokohkan Kebhinekaan: Strategi Meminimalisir Perdebatan}

Menurut responden upaya meminimalisir perdebatan disampaikan dalam berbagai persepsi. Persepsi responden yang menyatakan bahwa pemerintah harus hadir dalam permasalahan ini dan berdiri untuk semua golongan. Ini srtinya bahwa Pemerintah menjadi bagian untuk istiqamah dengan kebenaran serta kembali kepada Allah, Rasul dan pemimpin.

Menurut responden bahwa Indonesia sebagai Negara yang demokratis, memilih dan dipilih pemimpin secara langsung oleh rakyat nya. hal yang bisa diminimalisir adalah melalui ilmu pengetahuan masyarakatnya. pemimpin seperti apa yang akan mereka pilih, dalam memimpin hingga 5 tahun kedepan. tentu saja menurut saya yang harus di lihat adalah siapa dia, bagaimana latar belakangnya dan berfikir cerdas jangan mudah terprovokasi. Serta Seseorang pemimpin harus mengetahui dan menyadari apa yang menjadi tolak kur bagi dirinya maupun untuk orang lain.

Langkah strategis menjadi wadah mediasi perdebatan yang mengokohkan kebhinekaan di Indonesia menurut responden yaitu, Pertama, perbanyak dialog yang melibatkan semua elemen dan tingkatan. Sebetulnya pihak yang menjadi mediasi dalam perdebatan ini, adalah pihak yang tidak tersangkut dalam kegiatan politik, ya kegiatan politik tentunya memiliki tujuan yang berbeda. sehingga wadah mediasi adalah semua masyarakat Indonesia bersatu dalam visi dan misi yang sama untuk mengkokohkan bhineka tunggal ika. Kedua, dengan musyawarah sebagaimana disebutkan oleh sila ke empat Pancasila, Adanya sikap dan sifat terbuka antara pemerintah dengan masyarakatnya, sehingga tidak adanya suatu pemahaman yang berbeda-beda. Menegakkan hukum yang pasti sehingga masyarakat mengetahui rambu-rambu pemerintahan.

Menurut para responden jika pola musyawarah, dialog dan nilai nilai kebhinekaan dapat diterapkan yang menimbulkan empati maka akan tumbuh kesadaran dan keperdulian sesama terhadap Negara Indonesia, Ide dan langkah langkah strategis dapat diterima semua masyarakat. Termasuk hal hal yang bersifat sensitif, salah seorang reponden menegaskan:

Jikalau pengambil kebijakan sampai pimpinan partai yang akan mengusung calon pemimpin daerah (misalnya) sangat menyadari geografi, sosiologi, budaya dan keberagamaan bangsa Indonesia, maka tidak akan terjadi persoalan persoalan yang sensitif. Walaupun kegiatan yang terjadi menjadi bagian tolak ukur bagaimana satu umat melakukan demonstrasi yang dikoordinir olah para agamwan akan berimplikasi kedamaian dan kenyamanan seperti kasus aksi damai umat Islam.

Dari hasil analisis pernyataan responden bahwa konstruk “"Bersatu kita teguh, bercerai kita runtuh" harus tetap kokoh dan dipertahankan. Karena itu kekuatan musyawarah, memperkuat sendi hukum nasional dan kepastian hukum, serta meningkatkan Semangat Bhinneka Tunggal 
Ika. Sebab dari sisi manapun Indonesia sebagai negara kesatuan pada dasarnya dapat mengandung potensi kerawanan konflik sosial akibat akumulasi permasalahan Ideologi, politik, ekonomi, sosial budaya dan keamanan yang saling tumpang tindihal.

Bentuk-bentuk pengumpulan massa yang dapat menciptakan konflik horizontal maupun konflik vertikal harus dapat diantisipasi guna mendapatkan solusi tepat dan dapat meredam segala bentuk konflik yang terjadi. Kepemimpinan dari tingkat elit politik nasional hingga kepemimpinan daerah sangat menentukan untuk menanggulangi konflik pada skala dini. Upaya meminimalisir problem bangsa termasuk problem dalam penelitian ini dengan kesehatan fisik, kesehatan intelektual, kesehatan ideologi dan kesehatan spiritualitas. Sebab kebhinekaan merupakan fitrah bersifat top down dari Tuhan. Karena itu membangun dan menghidupkan terus komitmen, kesadaran dan kehendak untuk bersatu,membangun kelembagaan yang berakarkan nilai dan norma yang menyuburkan persatuan dan kesatuan bangsa. Serta dapat merumuskan kebijakan dan regulasi yang konkret, tegas dan tepat dalam aspek kehidupan dan pembangunan bangsa pro-religiusitas. Karenanya, kepemimpinan dari elit politik nasional hingga kepemimpinan daerah sangat menentukan meredamnya konflik pada skala dini.

Secara khusus persoalan pemimpin non muslim bisa memperlihatkan tiga gerakan atas hal tersebut. Pertama, Ahli hukum Islam yang mendasarkan semuanya berdasarkan padaeksteks keislaman, khususnya Al-Quran, Hadis, dan kitab-kitab tafsir dan telaah "fiqih siyasah". Pemikiran mereka ittiba atas kesimulan ulama klasik yang melarang pemimpin pemerintahan dari kalangan non muslim. Dalam beberapa kasus kelompok ini tetap memiliki keberagaman dari aspek pendapat. Seperti ulama Al-Azhar, Mesir yang tidak mempermasalahkanuntuk memilih pemimpin pemerintah non-Muslim. Dalil yang mereka pegang bahwa kata "auliya" itu tidak mengacu pada "pemimpin politik-pemerintahan".

Kedua, "kelompok politik" dalam wadah ormas atau tokoh-tokoh agama maupun organisasi politik atau tokoh-tokoh politik, aktivis partai politik. Apapun "baju” yang mereka pakai atau "bendera" yang mereka kibarkan, tetapi yang jelas muaranya adalah kepentingan politik praktis kekuasaan. Penelaahan mereka pada kepemimpinan non muslim tergantung pada situasi-kondisi yang menguntungkan dari aspek politik dan ekonomi. Kelompok ini menjadi agama sebagai kendaran politik. Ketiga, kelompok receh, mereka tidak memahami agama, tidak terlalu piawai mengenai politik, yang bekerja untuk melakukan tereakan saat demo dengan bayaran.

Sementara itu, dalam memilih pemimpin yang non muslim perlu diklasifikasikan menjadi dua: Pertama, memilih pemimpin non muslim di daerah mayoritas muslim; Kedua, memilih pemimpin non muslim di daerah minoritas muslim. Yang sering diperbincangkan adalah klasifikasi pertama, yaitu memilih pemimpin non muslim di daerah mayoritas muslim atau di wilayah muslim. Sedangkan memilih pemimpin non muslim di daerah minoritas muslim ada pengecualian. Yaitu sebagai suatu strategi untuk melindungi umat Islam dari bahaya yang akan menimpa mereka (Q.S. Ali Imron: 28). Munawir Sjadzali, dalam bukunya Islam dan Tata Negara (1990: 89-90 menuliskan bahwa

"Satu hal lagi yang menarik, Ibnu Taimiyah mendambakan ditegakkannya keadilan sede- 
mikian kuat, sehingga dia cenderung untuk beranggapan bahwa kepala negara yang adil meskipun kafir adalah lebih baik daripada kepala negara yang tidak adil meskipun Islam, dengan menyetujui ungkapan bahwa Allah mendukung negara yang adil meskipun kafir, dan bahwa Allah tidak mendukung negara yang tidak adil sekalipun Islam.”

\section{J. Kesimpulan}

Respon intelektual muda Pascasarjana UIN Raden Fatah atas kepemimpinan non muslim dalam 2 katagori pandangan. Pertama, Kemimpimpinan non muslim dapat saja terjadi diera sistem demokrasi di Indonesia. konsep dasar Negara Kesatuan Republik Indonesia (NKRI) yang dibangun oleh kebhinekaan yang tunggal ika, yang harus dimaknai sebagai media toleransi yang berlaku sama antar semua pihak.

Dalam sudut pandang kedua, tidak dapat dilakukan di wilayah mayoritas umat Islam. Hal tersebut sangat berhubungan dengan aqidahal. Pandangan paling mendasar bahwa umat Islam mayoritas dan memiliki orang orang yang mampu memimpin, mengapa kemudian harus berpikir ingin dipipimin oleh orang non muslim.

Selanjut langkah strategis mengokohkan kebhinekaan dengan meminimalisir perdebatan kepemimpinan non muslim perspektif intelektual muda Pascasarjana UIN Raden Fatah Palembang dengan membangun kesadaran semua pengusung suksesi kepemimpinan untuk memberikan kesadaran eksistensi bangsa Indonesia NKRI yang merupakan mayoritas umat Islam.

Pandangan lain memberikan solusi dengan mencoba mengukur semua dari nilai kinerja dengan tetap tidak menampikan keberagamaannya. Hal tersebut menjadi pertimbangan masyarakat dalam meningkatkan pengetahuan umum pemimpinnya. Maka seseorang yang berjiwa pemimpin dapat amanah dalam menjalankan tugasnya. Dan juga dengan adanya hal ini dapat membantu meningkatkan kesadaran masyarakat bahwasannya apa yang menjadi kepentingan terhadap umum dapat diwujudkan. Selanjutnya pemerintah harus hadir dalam permasalahan ini dan berdiri untuk semua golongan. Ini artinya bahwa Pemerintah menjadi bagian untuk istiqamah dengan kebenaran serta kembali kepada Allah, Rasul dan pemimpin

\section{Bibliografi}

Adinata, Surya Adinata, 2015, "Analisis terhadap Penafsiran FPI Mengenai Ayat Pemimpin Non-Muslim, Jurnal Ushuluddin, Vol.2, Nomor. 2. Januari-Juni

Ahmad, Rumadi "Pilkada Sehat dan Cerdas Tanpa Sara”, dalam Umar Syarifuddin, "Tentang Politisasi Agama, dari http://hizbut-tahrir.or.id,

Badruddin Al-Hamawi As-Syafi'i, 1988, Tahrirul Ahkam fi Tadbiri Ahlil Islam, Qatar: Daruts Tsaqafah 
Budiarjo, Miriam, 1987, Dasar-Dasar Ilmu Politik, Jakarta: Gramedia Pustaka Media,

Cholil, Suhadi, 2008, Resonansi Dialog Agama dan Budaya: Dari Kebebasan Beragama, Pendidikan Multikultural, Sampai RUU Anti Pornografi, Yogyakarta: Center for Religious \& Cross-Cultural Studies, Sekolah Pascasarjana, Universitas Gadjah Mada

Denny J.A.; Fransiskus Surdiasis, 2006, Catatan Politik, Yogyakarta : LKIS

Efendy, Bahtiar, 2002, Islam dan Negara: Transformasi Pemikiran dan Paktik Politik Islam di Indonesia, Jakarta: Paramadina

Ilham, 2016, Kepemimpinan Non Muslim: Respon Masyarakat Lenteng Agung Jakarta. Jakarta: UIN Syahid

Karim, Muljawan, 2000, Rindu Pancasila: Merajut Nusantara, Jakarta : Buku Kompas, 2010, hal. 5; Bonnie Setiawan, Perjuangan Demokrasi Dan Masyarakat Sipil : Reposisi dan Peran ORNOP/LMS di Indonesia, Jakarta: INFID

Khalik, Abu Tholib, 2014, Pemimpin Non-Muslim dalam Perspektif Ibnu Taimiyah, Analisis: Jurnal Studi Keislaman, Volume 14, Nomor 1, Juni

Latif, Yudi, Idi Subandy Ibrahim, 2011, Negara Paripurna: Historisitas, Rasionalitas, dan Aktualitas Pancasila, Jakarta : Gramedia Pustaka Utama,

Liddle, R. William, "Skripturalisme Media Dakwah: Sebuah Bentuk Pemikiran dan Aksi Politik Islam di Indonesia Masa Orde Baru”, dalam Mark R. Woodward (ed) 1998, Jalan Baru Islam: Memetakan Paradigma Murakhir Islam Indonesia, Bandung: Mizan

Mahir, Ahmad Agha, 2011, Yahudi; Catatan Hitam Sejarah, Terj. YodiIndrayadi, Jakarta: Qisthi Press,

Maliki, Zainudin, 2005, Agama Rakyat Agama Penguasa: Konstruksi Tentang Realitas Agama dan Demokratisasi, Jogjakarta: Galang Press

Mujar, Ibnu Syarif Mujar, 2006, Presiden Non Muslim: Tinjauan dari Perspektif Politik Islam dan Relevansinya dalam konteks Indonesia, Jakarta: Sinar Harapan

Naldi, Wahyu, 2015, fenafsiran Terhadap Ayat-Ayat Larangan Memilih Pemimpin NonMuslim Dalam Al-Qur'an (Studi Komparasi Antara M Quraish shihab dan Sayyid Quthb).Jogjakarta: UIN Suska

Noer, Deliar, 2003, Islam dan politik, Jakarta: Yayasan Risalah

Oneill, Jhon, 2009, Islam and Demise of Clasical civilization, USA: Ingram Book Group

Romli, Mohamad Guntur; Nong Darol Mahmada, 2013, Islam Tanpa Diskriminasi : Mewujudkan Islam Rahmatan Lil Alamin, Jakarta Rehal Pustaka

Sjadzali, Munawir, 1990, Islam dan Tata Negara: Ajaran, Sejarah dan Pemikiran, Jakarta: UI Press, 
Suyitno, Heri Junaidi, Abdul Hadi, 2009, Negara Bangsa Versus Negara Syariah, Jogjakarta: Gamamedia Pratama, 2009

Syamsuddin, M. Din, 1993, “Upaya Pencarian Konsep Tentang Negara Dalam Islam”, Jurnal Ulumul Qur’an, No.5, Vol. VI, Jakarta: LSAF

Syarifuddin, Rahmad, 2016, Pengangkatan Pemimpin Non-Muslim Dalam Al-Qur'an (Studi Penafsiran M.Quraish Shihab Dalam Tafsìr Al-Misbah, Semarang: UIN Wali Songo

Tripada, Arif, "Pro Kontra Memilih Pemimpin Non Muslim” dalam http://www.kompasiana.com

Wahid, Abdurrahman ; Kacung Marijan; Ma’mun Murod Al-Brebesy, 2000, Mengurai Hubungan Agama dan Negara, Jakarta : Grasindo

Wahid, Wawan Gunawan Abdul, 2015, Fikih Kebhinekaan, Bandung: Mizan 